\title{
Three Ganoderma species, including Ganoderma dunense sp. nov., associated with dying Acacia cyclops trees in South Africa
}

J. M. Tchotet Tchoumi ${ }^{1}$, M. P. A. Coetzee ${ }^{1}$, M. Rajchenberg ${ }^{2}$, M. J. Wingfield ${ }^{1} \&$ J. Roux ${ }^{3, *}$

${ }^{1}$ Department of Biochemistry, Genetics and Microbiology, Forestry and Agricultural Biotechnology Institute (FABI), Faculty of Natural and Agricultural Sciences (NAS), University of Pretoria,

Pretoria, South Africa

${ }^{2}$ Centro de Investigacion y Estension Forestal Andino Patagonico, Esquel, Chubut, Argentina

${ }^{3}$ Department of Plant and Soil Sciences, Forestry and Agricultural Biotechnology Institute (FABI), Faculty of Natural and Agricultural Sciences (NAS), University of Pretoria, Pretoria, South Africa

*Correspondence to: J. Roux, Jolanda.roux@gmail.com

\begin{abstract}
Large numbers of Acacia cyclops trees are dying along the coastal plains of the Eastern and Western Cape Provinces of South Africa. The cause of the deaths has been attributed to a root and butt rot disease caused by the basidiomycete fungus Pseudolagarobasidium acaciicola. However, many signs (e.g. basidiomes) and symptoms reminiscent of Ganoderma root-rot disease are commonly associated with dying trees. In this study, isolates collected from basidiomes resembling species of Ganoderma, as well as from root and butt samples from
\end{abstract}


diseased A. cyclops trees were subjected to DNA sequencing and morphological studies to facilitate their identification. Multi-locus phylogenetic analyses and morphological characterisation revealed that three species of Ganoderma are associated with dying A. cyclops trees. These included G. destructans, a recently described species causing root-rot on trees elsewhere in South Africa. The remaining two were novel species, one of which is described here as $G$. dunense. The novel species is distinguished by its mucronate basidiome, laccate shiny pileus surface, duplex context and ovoid basidiospores. Only an immature specimen was available for the second species and a name was consequently not provided for it. Interestingly, only a single isolate representing $P$. acaciicola was recovered in this study, suggesting that further investigations are needed to ascertain the role of each of the four basidiomycetous rootrot fungi in the death of A. cyclops trees.

Key words: Ganodermataceae, phylogeny, Pseudolagarobasidium, taxonomy, rooikrans, root rot

\section{INTRODUCTION}

Acacia cyclops A. Cunn. ex G. Don (Fabaceae) is a woody shrub that occurs mainly in arid and coastal areas due to its ability to withstand severe environmental pressures such as drought, soil salinity and sand blasts (Gill 1985). In South Africa, the first trees of this species were introduced from Australia in the early 1830's to contain and stabilise the movement of sand dunes in the coastal areas of the country, including the Eastern and Western Cape Provinces (Avis 1989). Subsequently, the shrub developed rapidly to become an invasive weed and a serious environmental threat because it forms tall, thick, and almost impenetrable stands that 
stifle the establishment of native plants (Henderson 1998, 2007). However, despite being detrimental to the diversity of local plants, A. cyclops trees also provide an important source of firewood, charcoal and construction materials (Shackleton et al. 2006).

During the course of the last four decades, A. cyclops trees have been dying along the coastal planes in the Eastern and Western Cape Provinces of South Africa, particularly between the towns of George and Stilbaai (Taylor 1969; Wood and Ginns 2006; Kotzé et al. 2015). The dying trees suffer from a rapidly developing root and butt-rot disease that results in die-back, wilt, and a white rot of the affected roots and root collars. The disease has been attributed to the basidiomycete root-rotting fungus Pseudolagarobasidium acaciicola Ginns (Wood and Ginns 2006; Kotzé et al. 2015). However, basidiomes of another fungus resembling a species of Ganoderma are also regularly seen attached to the bases of the dying trees, but no attempt has been made to determine the identity of this fungus (Taylor 1969; Wood and Ginns 2006).

The genus Ganoderma P. Karst. (Basidiomycota, Polyporales, Ganodermataceae) has a worldwide distribution and includes both saprophytic and parasitic species. They cause white rot on a wide range of host trees (Flood et al. 2000), but are also of significant medicinal and cultural importance (Bishop et al. 2015). Ganoderma species are known to kill a wide variety of trees, including those with high economic value such as rubber (Hevea brasiliensis Müll.Arg.), tea [Camellia sinensis (L.) Kuntze], oil palm (Elaeis guineensis Jacq.) and ornamental and forest trees (Ramasamy 1972; Paterson 2007; Kinge and Mih 2011; Coetzee et al. 2015). They are also the main causal agents of root and butt rot diseases of numerous Acacia species in tropical regions of the world (Glen et al. 2009; Coetzee et al. 2011). 
Identification and circumscription of species of Ganoderma has mainly relied on the description of morphological characteristics of the basidiomes, resulting in considerable taxonomic confusion (Richter et al. 2015). Most recently, the Phylogenetic Species Recognition (PSR) concept has improved species delimitation in the genus (Hong and Jung 2004, Zhou et al. 2015). Analyses of DNA sequences for loci such as the internal transcribed spacer (ITS: ITS15.8S-ITS2), the translation elongation factor 1- $\alpha$ (TEF1- $\alpha$ ) and $\beta$-tubulin, among others, have facilitated the inference of relationships between species of Ganoderma (Park et al. 2012; Zhou et al. 2015; Xing et al. 2016). At least 438 specific and infraspecific names are listed for Ganoderma in Index Fungorum (http://www.indexfungorum.org/names/Names.asp). It has however, been suggested that less than one third of these names are valid (Kirk et al. 2008; Richter et al. 2015).

Studies by Taylor (1969) and Wood and Ginns (2006) revealed the recurring presence of basidiomes reminiscent of Ganoderma attached to the bases of dying A. cyclops trees in the Western Cape Province of South Africa. However, having demonstrated in pathogenicity trials that $P$. acaciicola was the causal agent of the tree death, the authors did not attempt to determine the identity of the Ganoderma species associated with the declining trees (Wood and Ginns 2006). The report of Wood and Ginns (2006) suggests that a single Ganoderma species is associated with dying $A$. cyclops trees although this might not be the case. The objective of this study was to resolve the identity of the unknown Ganoderma species occurring on declining $A$. cyclops trees using DNA sequence comparisons for multiple gene regions as well as morphological observations. 


\section{MATERIALS AND METHODS}

Fungal collection and isolation

Basidiomes and recently infected roots and basal sections were collected from dying A. cyclops. Collection sites included areas close to the towns of Heroldsbaai and Stillbaai in the Western Cape Province and the Nelson Mandela Bay Metropolitan area (Port Elizabeth, PE) in the Eastern Cape Province (Fig. 1). Isolations were performed on a basidiomycete selective medium composed of 2\% Malt Extract Agar (MEA) [20 g/L malt extract and $15 \mathrm{~g} / \mathrm{L}$ agar, Biolab, Midrand, South Africa] supplemented with benomyl, dichloran and streptomycin (BDS) as outlined in Worrall (1991). Small pieces of wood (approximately 2-3 $\mathrm{mm}^{3}$ ) from both infected basal sections and roots were first surface-disinfested in $7 \%$ bleach $(\mathrm{NaClO})$ for $\sim 90 \mathrm{~s}$ and rinsed twice with sterile distilled water before transferring them to the selective medium. Isolations from basidiomes were carried out by placing small sections $(2-3 \mathrm{~mm})$ obtained from the hymenophore onto the selective medium. 


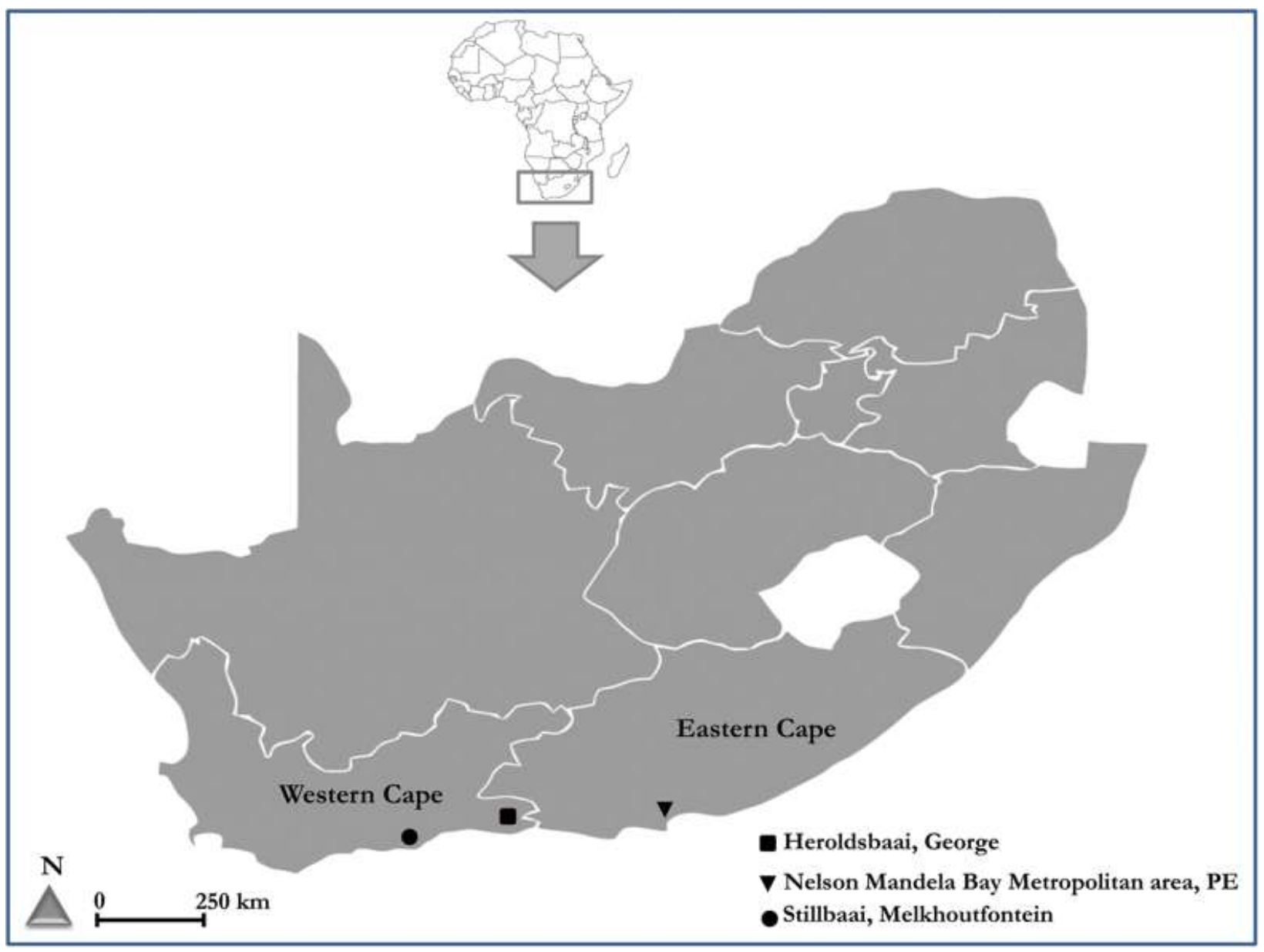

Fig. 1 South Africa map showing the sites in the Eastern and Western Cape Provinces where specimens of Ganoderma on Acacia cyclops were sampled. PE stands for Port Elizabeth

After 7-10 days of incubation at room temperature $\left(22-24^{\circ} \mathrm{C}\right)$, pure cultures were obtained by aseptically transferring small pieces of the growing margin of the fungal isolates onto fresh 2\% MEA. Two mature cultures of each isolate were preserved in the culture collection (CMW) of the Forestry and Agricultural Biotechnology Institute (FABI), University of Pretoria, South Africa. Representative isolates were deposited in the culture collection (CBS) of the Westerdijk Fungal Biodiversity Institute, Utrecht, The Netherlands. Dried basidiomes were also deposited in the herbarium of the South African National Collection of Fungi (PREM), Roodeplaat, South Africa. 


\section{Genomic DNA extraction, amplification and sequencing}

Genomic DNA was extracted from cultures (Table 1) following the Cetyltrimethylammonium Bromide (CTAB) extraction protocol described by Möller et al. (1992). DNA concentrations were determined with a NanoDrop ${ }^{\circledR}$ ND-1000 spectrophotometer (NanoDrop Technologies, Wilmington, DE, USA). Working DNA concentrations for polymerase chain reactions (PCRs) were obtained by adjusting the initial concentrations of the extracted genomic DNA to 100 $\mathrm{ng} / \mu \mathrm{L}$. The complete internal transcribed spacer (ITS) region, including ITS-1, ITS-2 and the 5.8S small subunit gene was amplified for all isolates using primers ITS1 and ITS4 (White et al. 1990). Amplifications of the partial translation elongation factor 1- $\alpha$ (TEF1- $\alpha)$ and partial $\beta$ tubulin gene regions were obtained using primer pairs EF595F/EF1160R (Kauserud and Schumacher 2001) and $\beta$-tubulin_F/ $\beta$-tubulin_R (Park et al. 2012), respectively.

All PCR reactions were carried out in $25 \mu \mathrm{L}$ total mixtures consisting of $17.5 \mu \mathrm{L}$ sterile SABAX water (Adcock Ingram Ltd, Bryanston, RSA), $1 \mu \mathrm{L}$ genomic DNA (100 ng $\mu \mathrm{L}), 0.5 \mu \mathrm{L}$ (2.5 units) of MyTaq ${ }^{\mathrm{TM}}$ DNA polymerase (Bioline), $5 \mu \mathrm{L} 5$ x MyTaq ${ }^{\mathrm{TM}}$ Reaction Buffer supplied with the enzyme and $0.5 \mu \mathrm{L}(10 \mathrm{mM})$ of each primer. The PCR conditions used with primers ITS1/ITS4 and EF595F/EF1160R were as follows: an initial denaturation step at $95^{\circ} \mathrm{C}$ for $4 \mathrm{~min}$, followed by 35 cycles of denaturation at $95^{\circ} \mathrm{C}$ for $30 \mathrm{~s}, 30 \mathrm{~s}$ of annealing at $55^{\circ} \mathrm{C}$ and $60 \mathrm{~s}$ of extension at $72^{\circ} \mathrm{C}$. The reactions were completed with a final elongation step at $72^{\circ} \mathrm{C}$ for $7 \mathrm{~min}$. Amplifications with the $\beta$-tubulin_F/ $\beta$-tubulin_R primers were carried out with the same parameters as those used by Park et al. (2012). PCR products were electrophoresed on $2 \%$ agarose gels after staining with GelRed ${ }^{\mathrm{TM}}$ nucleic acid dye (Biotium Incorporation, USA) and visualized under UV illumination. Sephadex G-50 columns (Sigma, Steinheim, Germany) were then used to purify the PCR products following the recommendations of the manufacturer. 
Table 1. Isolates used in the phylogenetic analyses

\begin{tabular}{|c|c|c|c|c|c|}
\hline \multirow[t]{2}{*}{ Species } & \multirow[t]{2}{*}{ Voucher no. } & \multirow[t]{2}{*}{ Geographical origin } & \multicolumn{3}{|c|}{ GenBank accession numbers } \\
\hline & & & ITS & $\beta$-tubulin & TEF1- $\alpha$ \\
\hline Ganoderma adspersum & Yao34456 & United Kingdom & AJ006685 & - & - \\
\hline G. applanatum & Dai 12483 & China & KF494999 & - & KF494977 \\
\hline G. applanatum & ATCC 44053 & Japan & JQ520161 & JQ675614 & - \\
\hline G. aridicola & Dai12588 (holotype) & South Africa & KU572491 & - & KU572502 \\
\hline G. austroafricanum & CMW 41454 & South Africa & KM507324 & - & - \\
\hline G. boninense & WD 2028 & Japan & KJ143905 & - & KJ143924 \\
\hline G. boninense & WD 2085 & Japan & KJ143906 & - & KJ143925 \\
\hline G. carnosum & MJ 21/08 & Czech Republic & KU572492 & - & - \\
\hline G. carnosum & JV 8709/8 & Czech Republic & KU572493 & - & - \\
\hline G. carnosum & CBS 516.96 & Netherlands & - & JQ675616 & - \\
\hline G. cupreum & GanoTK4 & Cameroon & JN105701 & - & - \\
\hline G. cupreum & GanoTK7 & Cameroon & JN105702 & - & - \\
\hline G. curtisii & CBS 100131 & United States of America (USA) & JQ781848 & - & KJ143926 \\
\hline G. curtisii & CBS 100132 & USA & JQ781849 & - & KJ143927 \\
\hline G. curtisii & CBS 100132 & Netherlands & - & JQ675617 & - \\
\hline G. destructans & CBS 139793 (type) & South Africa & NR132919 & MG020151* & MG020213* \\
\hline G. destructans & CMW 43671 & South Africa & KR183857 & MG020156* & MG020220* \\
\hline G. destructans & CMW42129 & South Africa & MG020232 & MG020158 & MG020191 \\
\hline G. destructans & CMW42130 & South Africa & MG020233 & MG020159 & MG020192 \\
\hline G. destructans & CMW42131 & South Africa & MG020234 & MG020160 & MG020193 \\
\hline G. destructans & CMW42134 & South Africa & MG020235 & MG020161 & MG020216 \\
\hline G. destructans & CMW42135 & South Africa & MG020236 & MG020162 & MG020214 \\
\hline G. destructans & CMW42136 & South Africa & MG020237 & MG020163 & MG020194 \\
\hline G. destructans & CMW42137 & South Africa & MG020238 & MG020164 & MG020195 \\
\hline G. destructans & CMW42138 & South Africa & MG020239 & MG020165 & MG020196 \\
\hline G. destructans & CMW42139 & South Africa & MG020240 & MG020166 & MG020197 \\
\hline G. destructans & CMW42140 & South Africa & MG020241 & MG020167 & MG020215 \\
\hline G. destructans & CMW42141 & South Africa & MG020242 & MG020168 & MG020198 \\
\hline G. destructans & CMW42142 & South Africa & MG020243 & MG020169 & MG020199 \\
\hline
\end{tabular}


Table 1. (continued)

\begin{tabular}{|c|c|c|c|c|c|}
\hline \multirow[t]{2}{*}{ Species } & \multirow[t]{2}{*}{ Voucher no. } & \multirow[t]{2}{*}{ Geographical origin } & \multicolumn{3}{|c|}{ GenBank accession numbers } \\
\hline & & & ITS & $\beta$-tubulin & TEF1- $\alpha$ \\
\hline G. destructans & CMW42143 & South Africa & MG020244 & MG020170 & MG020221 \\
\hline G. destructans & CMW42146 & South Africa & MG020245 & MG020171 & MG020200 \\
\hline G. destructans & CMW42147 & South Africa & MG020246 & MG020172 & MG020201 \\
\hline G. destructans & CMW42148 & South Africa & MG020247 & MG020173 & MG020202 \\
\hline G. destructans & CMW42151 & South Africa & MG020250 & MG020174 & MG020203 \\
\hline G. destructans & CMW42152 & South Africa & MG020251 & MG020175 & MG020204 \\
\hline G. destructans & CMW42153 & South Africa & MG020252 & MG020176 & MG020205 \\
\hline G. destructans & CMW42154 & South Africa & MG020253 & MG020177 & MG020206 \\
\hline G. destructans & CMW42155 & South Africa & MG020254 & MG020178 & MG020217 \\
\hline G. destructans & CMW42158 & South Africa & MG020256 & MG020179 & MG020224 \\
\hline G. destructans & CMW42159 & South Africa & MG020257 & MG020180 & MG020223 \\
\hline G. destructans & CMW42160 & South Africa & MG020258 & MG020181 & MG020207 \\
\hline G. destructans & CMW42161 & South Africa & MG020259 & MG020182 & MG020208 \\
\hline G. destructans & CMW42162 & South Africa & MG020260 & MG020183 & MG020209 \\
\hline G. destructans & CMW42163 & South Africa & MG020261 & MG020184 & MG020218 \\
\hline G. destructans & CMW42164 & South Africa & MG020262 & MG020185 & MG020210 \\
\hline G. destructans & CMW42165 & South Africa & MG020263 & MG020186 & MG020211 \\
\hline G. destructans & CMW45109 & South Africa & MG020266 & MG020187 & MG020225 \\
\hline G. destructans & CMW45110 & South Africa & MG020267 & MG020188 & MG020222 \\
\hline G. destructans & CMW45113 & South Africa & MG020268 & MG020189 & MG020212 \\
\hline G. destructans & CMW45114 & South Africa & MG020269 & MG020190 & MG020219 \\
\hline G. dunense sp. nov & CMW42149 & South Africa & MG020248 & MG020153 & MG020226 \\
\hline G. dunense sp. nov & CMW42150 & South Africa & MG020249 & MG020154 & MG020228 \\
\hline G. dunense sp. nov & CMW42157 (Type) & South Africa & MG020255 & MG020150 & MG020227 \\
\hline G. gibbosum & $\mathrm{XSD}-35$ & Unknown & EU273514 & - & - \\
\hline G. gibbosum & AS5.624 type 3 & China & AY593856 & - & - \\
\hline G. enigmaticum & Dai 15970 & Africa & KU572486 & - & KU572496 \\
\hline G. enigmaticum & Dai 15971 & Africa & KU572487 & - & KU572497 \\
\hline G. enigmaticum & CBS 139792 (type) & South Africa & NR132918 & MG020157* & MG020231* \\
\hline
\end{tabular}


Table 1. (continued)

\begin{tabular}{|c|c|c|c|c|c|}
\hline \multirow[t]{2}{*}{ Species } & \multirow[t]{2}{*}{ Voucher no. } & \multirow[t]{2}{*}{ Geographical origin } & \multicolumn{3}{|c|}{ GenBank accession numbers } \\
\hline & & & ITS & $\beta$-tubulin & TEF1- $\alpha$ \\
\hline G. leucocontextum & Dai 15601 & China & KU572485 & - & KU572495 \\
\hline G. leucocontextum & GDGM 44489 & China & KM396271 & - & - \\
\hline G. lingzhi & Wu 1006-38 (holotype) & China & JQ781858 & - & JX029976 \\
\hline G. lingzhi & Dai 12574 & China & KJ143908 & - & JX029977 \\
\hline G. lingzhi & Dai 12479 & China & JQ781864 & - & JX029975 \\
\hline G. lobatum & JV 0409/13J & USA & KF605675 & - & - \\
\hline G. lobatum & JV 1212/10J & USA & KF605676 & - & KU572501 \\
\hline G. lobatum & ATCC 42985 & Canada & - & JQ675618 & - \\
\hline G. lobatum & ASI 7061 & USA & - & JQ675619 & - \\
\hline G. lucidum & Cui 9207 & China & KJ143910 & - & KJ143928 \\
\hline G. lucidum & K 175217 & UK & KJ143911 & - & KJ143929 \\
\hline G. lucidum & ASI 7117 & Korea & - & JQ675633 & - \\
\hline G. lucidum & IUM 4303 & Bangladesh & - & JQ675635 & - \\
\hline G. lucidum & IUM 0047 & Korea & - & JQ675627 & - \\
\hline G. meredithae & ATCC 64492 & USA & - & JQ675643 & - \\
\hline G. meredithae & ASI 7140 & Unknown & - & JQ675644 & - \\
\hline G. mirabile & CBS 218.36 & Philippines & - & JQ675645 & - \\
\hline G. multipileum & CWN 04670 & China & KJ143913 & - & KJ143931 \\
\hline G. multipileum & Dai 9447 & China & KJ143914 & - & KJ143932 \\
\hline G. multiplicatum & Dai 12320 & China & - & - & KU572500 \\
\hline G. multiplicatum & Dai 13710 & China & - & - & KU572499 \\
\hline G. mutabile & Yuan 2289 (type) & China & JN383977 & - & - \\
\hline G. neојаропісит & ASI 7032 & Unknown & - & JQ675646 & - \\
\hline G. oerstedii & GO138 & Unknown & - & DQ288098 & - \\
\hline G. oregonense & CBS 265.88 & USA & JQ781875 & NS & KJ143933 \\
\hline G. oregonense & ASI 7049 & USA & - & JQ675647 & - \\
\hline G. oregonense & ASI 7067 & USA & - & JQ675650 & - \\
\hline G. oregonense & CBS 266.88 & USA & JQ781876 & - & - \\
\hline G. pfeifferi & CBS 747.84 & Netherlands & - & JQ675651 & - \\
\hline
\end{tabular}


Table 1. (continued)

\begin{tabular}{|c|c|c|c|c|c|}
\hline \multirow[t]{2}{*}{ Species } & \multirow[t]{2}{*}{ Voucher no. } & \multirow[t]{2}{*}{ Geographical origin } & \multicolumn{3}{|c|}{ GenBank accession numbers } \\
\hline & & & ITS & $\beta$-tubulin & TEF1- $\alpha$ \\
\hline G. philippii & E7098 & Indonesia & AJ536662 & - & - \\
\hline G. philippii & E7092 & Indonesia & AJ608710 & - & - \\
\hline G. resinaceum & BR 4150 & France & KJ143915 & - & - \\
\hline G. resinaceum & CBS 194.76 & Netherlands & KJ143916 & - & KJ143934 \\
\hline G. resinaceum & ATCC 52416 & Argentina & - & JQ675652 & - \\
\hline G. resinaceum & IUM 3651 & Czech Republic & - & JQ675657 & - \\
\hline G. ryvardenii & HKAS 58055 & Cameroon & HM138670 & - & - \\
\hline G. ryvardenii & HKAS 58053 (type) & Cameroon & HM138671 & - & - \\
\hline G. sessile & JV $1209 / 9$ & USA & KF605629 & - & KJ143936 \\
\hline G. sessile & LDW 20121017 & USA & KJ143917 & - & KJ143935 \\
\hline G. sinense & Wei 5327 & China & KF494998 & - & KF494976 \\
\hline Ganoderma sp. A & CMW45100 & South Africa & MG020264 & MG020152 & MG020229 \\
\hline Ganoderma sp. A & CMW45101 & South Africa & MG020265 & MG020155 & MG020230 \\
\hline Ganoderma sp. & ASI 7150 & Unknown & - & JQ675665 & - \\
\hline Ganoderma sp. & ASI 7151 & Unknown & - & JQ675666 & - \\
\hline G. subamboinens & GSUB136 & Unknown & - & DQ288096 & - \\
\hline G. subamboinens & GSUB137 & Unknown & - & DQ288097 & - \\
\hline G. tепие & GTEN24 & Unknown & - & DQ288074 & - \\
\hline G. tornatum & CBS 109679 & Netherlands & - & JQ675670 & - \\
\hline G. tornatum & BAFC1172 & Argentina & AH008096 & - & - \\
\hline G. tornatum & BAFC1139 & Argentina & AH008098 & - & - \\
\hline G. tropicum & He 1232 & China & KF495000 & - & KF494975 \\
\hline G. tropicum & Yuan 3490 & China & JQ781880 & - & KJ143938 \\
\hline G. tsugae & Dai $12751 b$ & USA & KJ143919 & - & KJ143939 \\
\hline G. tsugae & Dai 12760 & USA & KJ143920 & - & KJ143940 \\
\hline G. tsugae & ATCC 64795 & Canada & - & JQ675668 & - \\
\hline G. tsugae & ASI 7064 & USA & - & JQ675669 & - \\
\hline G. valesiacum & CBS 428.84 & USA & - & JQ675671 & - \\
\hline G. webeianum & CBS 219.36 & Philippines & - & JQ675672 & - \\
\hline
\end{tabular}


Table 1. (continued)

\begin{tabular}{|c|c|c|c|c|c|}
\hline \multirow[t]{2}{*}{ Species } & \multirow[t]{2}{*}{ Voucher no. } & \multirow[t]{2}{*}{ Geographical origin } & \multicolumn{3}{|c|}{ GenBank accession numbers } \\
\hline & & & ITS & $\beta$-tubulin & TEF1- $\alpha$ \\
\hline G. zonatum & FL-02 & USA & KJ143921 & - & KJ143941 \\
\hline G. zonatum & FL-03 & USA & KJ143922 & - & KJ143942 \\
\hline Tomophagus colossus & TC-02 & Vietnam & KJ143923 & - & KJ143943 \\
\hline Trametes suaveolens & - & Unknown & - & FJ410378 & - \\
\hline
\end{tabular}

Reference sequences with star $(*)$ are those generated in this study. In bold are isolates of the newly proposed species. 
Purified PCR products were sequenced in $12 \mu \mathrm{L}$ reaction volumes using the same primer pairs as in the amplification reactions. DNA sequencing reactions were done using Big Dye (Perkin-Emmer, Warrington, UK), following the protocol outlined by the manufacturer. Purification of the sequencing PCR products followed the same approach as for the PCR products. DNA sequencing was carried out on a DNA Analyzer ABI PRISMTM 3100 (Applied BioSystems, Foster City, CA, USA) at the sequencing facility of the University of Pretoria. CLC Main Workbench v7.6.1 was used to assess the quality of the electropherograms and to construct consensus sequences. DNA sequences of the $\beta$-tubulin and TEF1- $\alpha$ gene regions of $G$. destructans and G. enigmaticum, previously described from South Africa (Coetzee et al. 2015), were also generated for comparative purposes. These sequences as well as those of the novel species were deposited in GenBank.

DNA sequence datasets and multi-gene phylogenetic analysis

Preliminary identification based on BLASTn searches of ITS sequences against those of reference sequences in GenBank was made to confirm that the sequences of the fungal isolates from A. cyclops were species of Ganoderma. Phylogenetic analyses were subsequently performed to determine the phylogenetic placement of the isolates from A. cyclops. For this purpose, four sequence datasets were generated. Of these, three represented the ITS, $\beta$-tubulin and TEF1- $\alpha$ gene regions alone, and one consisted of the combined sequences for all three loci. In addition to sequences generated in this study, the datasets also included reference sequences used in previous studies, including those of Glen et al. (2009), Douanla-Meli et al. (2009), Kinge et al. (2012), Park et al. (2012), Zhou et al. (2015), Coetzee et al. (2015), Xing et al. (2016) (Table 1). Tomophagus colossus (Fr.) C.F. Baker and Trametes suaveolens (L.) Fr. were selected as outgroup taxa. Sequence alignments were performed using the online version of MAFFT 
(http://mafft.cbrc.jp/alignment/server/index.html) v7 (Katoh and Standley 2013), and the phylogenetic relationships between taxa were evaluated using Maximum Likelihood (ML), Maximum Parsimony (MP) and Bayesian Inference (BI) analyses. The GTR+G+I substitution model determined by JModeltest v2.1.6 (Darriba et al. 2012) on CIPRES (Miller et al. 2012) under the Akaike Information Criterion (AIC) was selected as the best-fit nucleotide substitution model and incorporated in the phylogenetic analyses.

Maximum likelihood analyses were performed in RaxML (Stamatakis 2006) using raxmlGUI 1.3 (Silvestro and Michalak 2012) with 10 parallel runs. Maximum likelihood bootstrap (MLB) analysis was done using 1000 replications. For BI analyses, four parallel runs, each with four Monte Carlo Markov Chains (MCMC) were performed using MrBayes v3.2 (Ronquist et al. 2012). Sampling of trees was carried out for four million generations with trees sampled at every $100^{\text {th }}$ generation. The first $25 \%$ of the sampled trees were discarded as burn-in and the Bayesian posterior probabilities (BPP) were calculated for the remaining trees. Maximum Parsimony analyses were performed in PAUP* version 4.0b10 (Swofford 2002). A heuristic search option with a tree bisection-reconnection (TBR) branch swapping algorithm, involving 100 random stepwise additions of sequences, was used to generate the most parsimonious trees. All characters were of equal weight, gaps were treated as missing data and tree branches of zero length were collapsed. The robustness of clades at the branch nodes was estimated using bootstrap (MPB) with 1000 replicates and using the same settings to obtain the fundamental tree but with the addition of sequences set to closest. Other estimated parameters included tree length (TL), consistency index (CI), retention index (RI), rescaled consistency index (RC), and homoplasy index (HI). The generated phylogenetic trees were visualized using MEGA 5.05 (Tamura et al. 2011). 


\section{Morphology}

Microscopic observations were made from fine sections of basidiomes mounted on microscope slides in $5 \% \mathrm{KOH}$ (potassium hydroxide) with and without $1 \%$ phloxine and Melzer's reagent (IKI). The observations were made using a Nikon Eclipse $\mathrm{N} i$ compound microscope (Nikon, Japan) at a magnification of up to 100x under an oil-immersion objective, and on a Zeiss Stemi SV6 stereo microscope. Images of the microscopic structures were captured with a Nikon DSRi2 camera fitted on the microscope and the measurements were made using the program NISElements BR (Nikon Instruments Software-Elements Basic research).

\section{RESULTS}

Signs and Symptoms

Typical signs and symptoms of Ganoderma root rot disease (Glen et al. 2009; Coetzee et al. 2011) were observed on the declining A. cyclops trees. These included crown wilt and die-back, fresh basidiomes of Ganoderma attached to the bases of the affected trees (Fig. 2a), basal cankers and butt rot (Fig. 2b), and roots with red rhizomorphic encrusting sheets covering a whitish mycelial mat (Fig. 2c). 

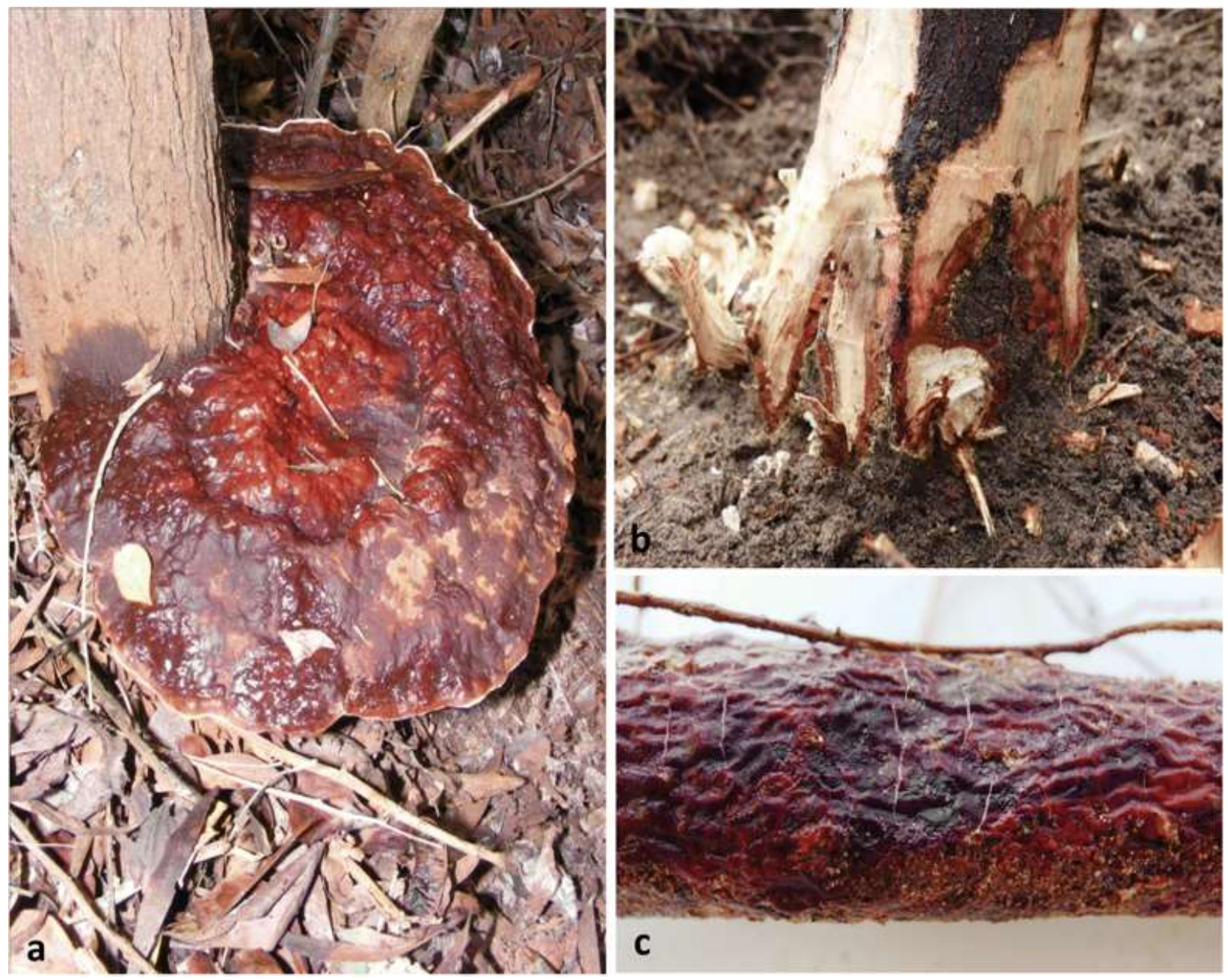

Fig. 2 Signs and symptoms of Ganoderma species infecting Acacia cyclops in South Africa. (a) Basidiome of $G$. destructans with reddish brown (laccate shiny) pilear surface attached to the base of wilting tree, (b) Collar rot, (c) Reddish brown to dark brown rhizomorphic sheet of a Ganoderma sp. covering root of dying tree

\section{Fungal Isolates}

In total, 38 isolates resembling species of Ganoderma were obtained from a total of 55 diseased and dying trees. Of these, three were isolated from roots covered with red-coloured rhizomorphic sheets; three from roots without rhizomorphic sheets; five from tree bases and the remaining 27 from fresh basidiomes (Table 1). The isolates in culture were either white to yellowish or completely yellow and ranged from having flat to fluffy mycelial growth. 


\section{DNA sequence comparisons}

The ITS, $\beta$-tubulin and TEF1- $\alpha$ gene regions of the 38 isolates were successfully amplified using PCR, and DNA sequences were obtained for all the amplicons. Results of BLASTn searches based on ITS revealed that 36 isolates had a high level of DNA sequence similarity with Ganoderma destructans. Two others (CMW45100, CMW45101) had a high level of sequence similarity with G. applanatum (Pers.) Pat. and G. gibbosum (Blume \& T. Nees) Pat. Besides the 38 Ganoderma isolates, a single isolate that was obtained from roots without rhizomorphic sheets was identified as $P$. acaciicola, and it was excluded from the rest of the study.

\section{Sequence data and multi-gene phylogenetic analyses}

The ITS dataset comprised of 89 ingroup taxa and one outgroup taxon. The dataset resulted in an alignment length of 651 characters, of which 357 were constant, 61 parsimony-uninformative and 233 parsimony-informative. The heuristic search resulted in eight parsimonious trees with $\mathrm{TL}=540, \mathrm{CI}=0.622, \mathrm{RI}=0.899$ and $\mathrm{RC}=0.559$. Since the tree topologies resulting from the $\mathrm{BI}, \mathrm{ML}$ and MP analyses were nearly identical, only the ML tree is presented, along with the statistical values (BPP and Bootstrap values) of the two other analyses (Fig. 3). In the phylogenetic tree of the ITS sequence data, the isolates generated from A. cyclops formed two groups, clustering at distant positions. The first group, composed of 36 isolates, formed a monophyletic clade with isolates representing G. destructans and G. multipileum. However, this clade had statistical support only in the ML analysis (75\% bootstrap support). The second group, comprised of isolates CMW45100 and CMW45101, nested in a strongly supported clade (MLB $=93 \%, \mathrm{MPB}=100 \%$ and $\mathrm{BPP}=1)$ with isolates representing G. applanatum, G. gibbosum and 


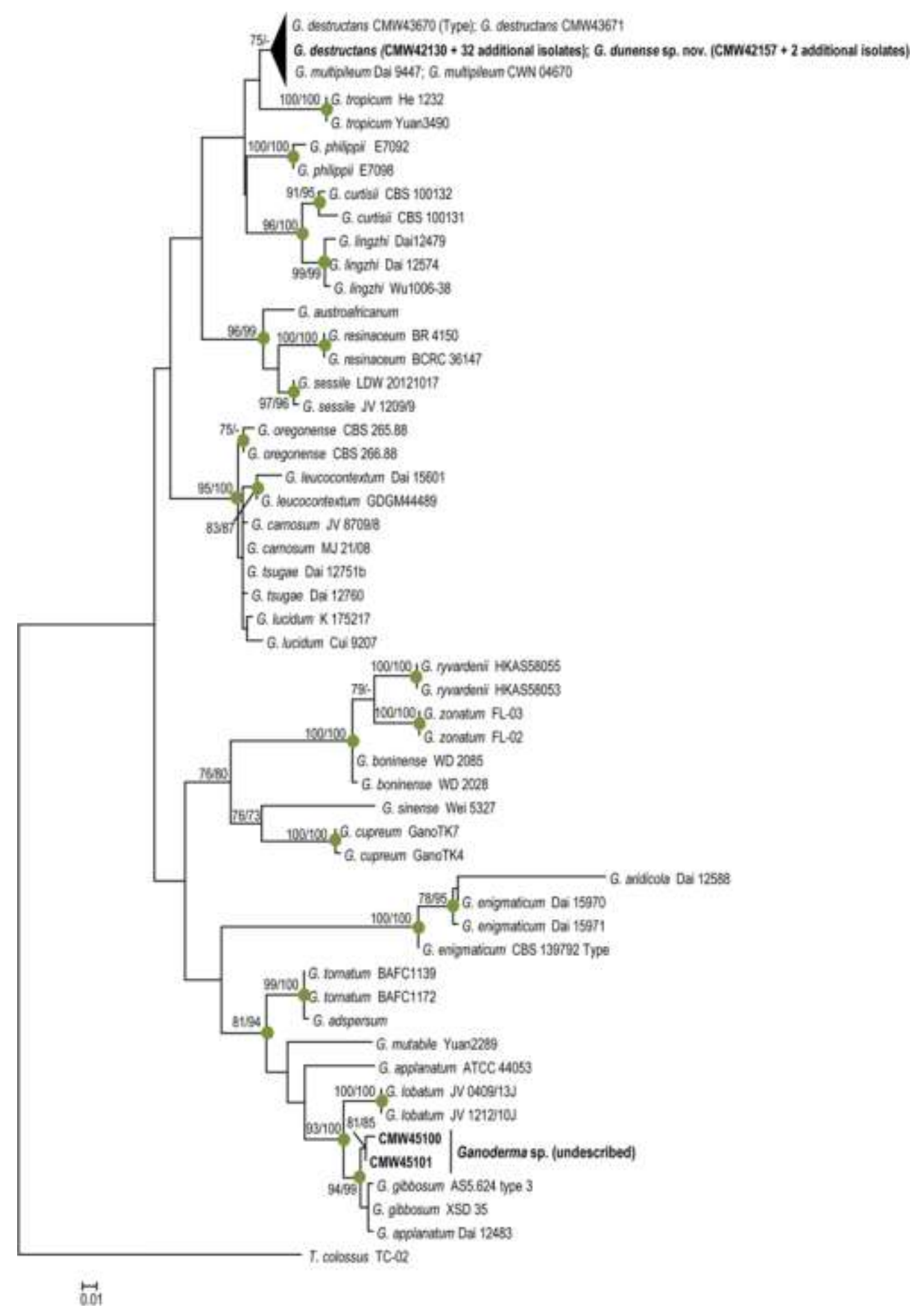

Fig. 3 Maximum likelihood tree based on ITS sequences, depicting the phylogenetic position of isolates obtained from Acacia cyclops (in bold) and related species within Ganoderma. Bootstrap values $\geq 70 \%$ from 1000 replicates of ML and MP analyses are displayed at the nodes. Posterior probability $\geq 0.95$ from Bayesian Inference analysis are indicated at nodes with green circles 
G. lobatum (Schwein.) G.F. Atk. However, the two A. cyclops isolates formed a well-resolved sub-clade, although not sufficiently supported by BI analysis (BPP $\leq 0.95)$.

The $\beta$-tubulin sequence dataset consisted of 68 taxa, which resulted in an alignment length of 401 total characters. Of the total number of characters, 277 were constant, 44 were parsimony-uninformative and 80 parsimony-informative. The heuristic search yielded 100 parsimonious trees with $\mathrm{TL}=206, \mathrm{CI}=0.544, \mathrm{RI}=0.887$ and $\mathrm{RC}=0.482$. Only the ML consensus tree incorporating the statistical values of BI and MP is presented (Fig. 4) since the three analyses yielded almost congruent topologies. In the $\beta$-tubulin phylogeny, unlike that for the ITS dataset, the isolates obtained from A. cyclops clustered at three different positions (Fig. 4). Thirty-three isolates (generated in this study) formed a monophyletic clade having strong statistical support with sequences representing $G$. destructans $(\mathrm{MLB}=82 \%, \mathrm{MPB}=98 \%, \mathrm{BPP}=$ 0.96). Three other isolates (CMW42149, CMW42150 and CMW42157) grouped in a wellresolved and strongly supported monophyletic cluster (MLB and MPB $=99 \%$, BPP $=1$ ), while the third group comprising isolates CMW45100 and CMW45101 formed another strongly supported clade $(\mathrm{MLB}$ and $\mathrm{MPB}=100 \%, \mathrm{BPP}=1)$ that was closely related to the lineage including G. mirabile and G. applanatum.

The dataset from TEF1- $\alpha$ contained 71 ingroup taxa and one outgroup taxon. The total number of characters after alignment of the dataset was 579 , of which 375 were constant, 35 were parsimony-uninformative and 169 parsimony-informative. The heuristic search resulted in 100 parsimonious trees with $\mathrm{TL}=435, \mathrm{CI}=0.584, \mathrm{RI}=0.885$ and $\mathrm{RC}=0.517$. The three analyses resulted in almost identical tree topologies. Hence, only the ML tree is shown alongside with BI and MP statistical values. As with $\beta$-tubulin, the TEF1- $\alpha$ phylogeny placed the isolates from A. cyclops at three different positions (Fig. 5). The first group, consisting of the same 33 


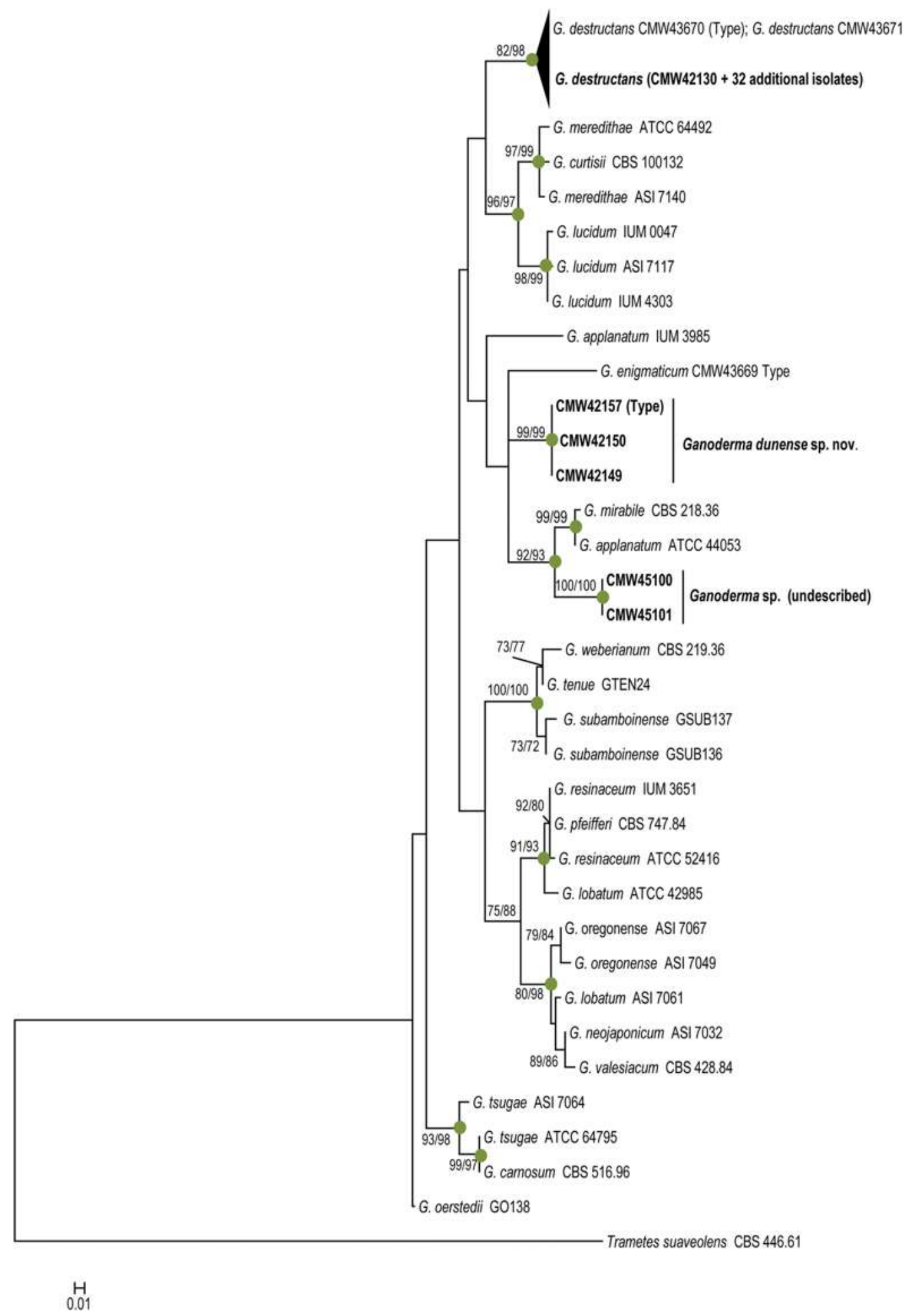

Fig. 4 Maximum likelihood tree based on $\beta$-Tubulin sequences, depicting the phylogenetic position of isolates obtained from Acacia cyclops (in bold) and related species within Ganoderma. Bootstrap values $\geq 70 \%$ from 1000 replicates of ML and MP analyses are displayed at the nodes. Posterior probability $\geq 0.95$ from Bayesian Inference analysis are indicated at nodes with green circles 


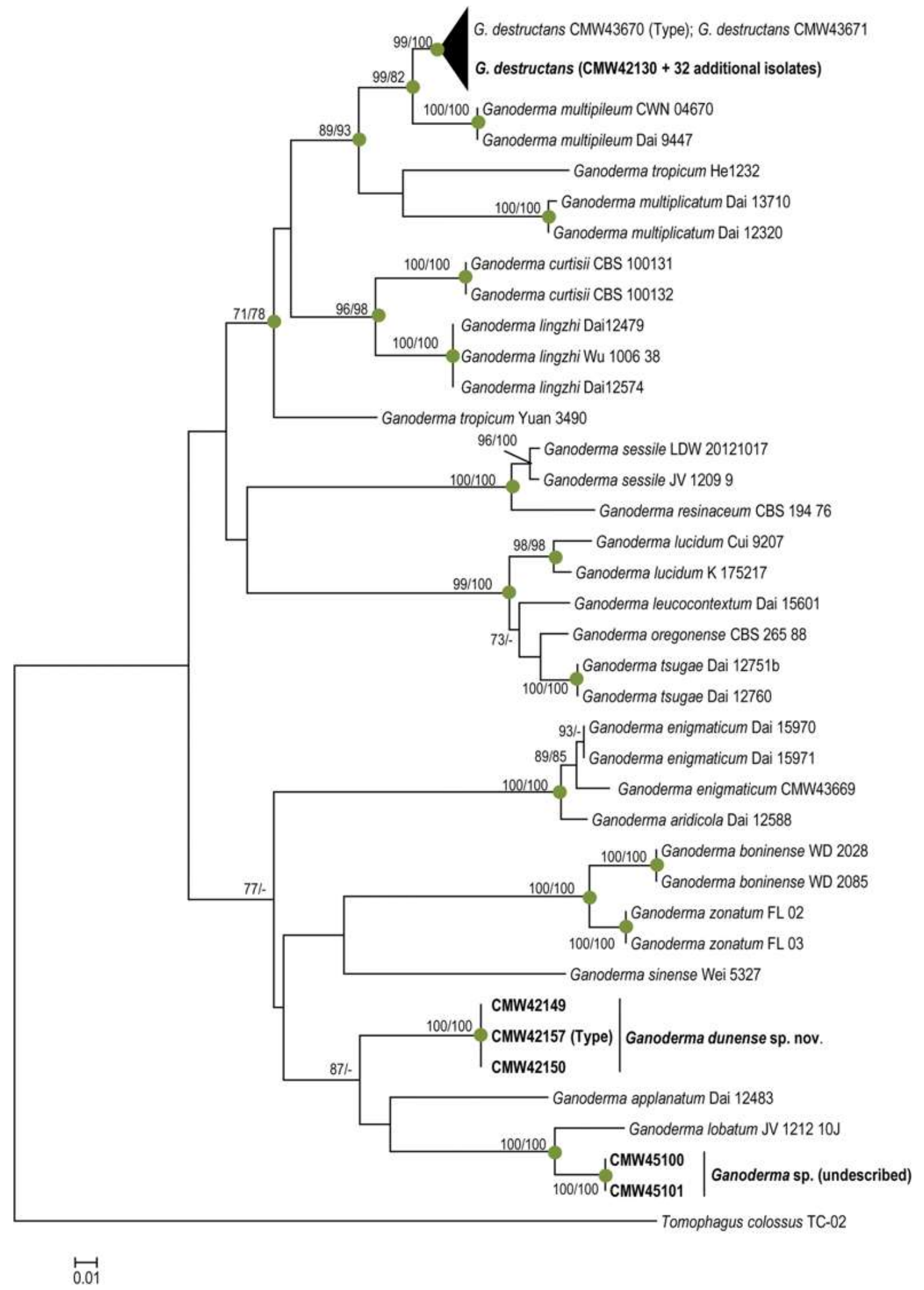

Fig. 5 Maximum likelihood tree based on TEF1- $\alpha$ gene sequences, depicting the phylogenetic position of isolates obtained from Acacia cyclops (in bold) and related species within Ganoderma. Bootstrap values $\geq 70 \%$ from 1000 replicates of ML and MP analyses are displayed at the nodes. Posterior probability $\geq 0.95$ from Bayesian Inference analysis are indicated at nodes with green circles 
isolates as in the $\beta$-tubulin gene tree, formed a strongly supported monophyletic clade (MLB = $99 \%, \mathrm{MPB}=100 \%, \mathrm{BPP}=0.98)$ with sequences representing $G$. destructans (generated in this study). This group was closely related to the lineage representing G. multipileum. The second group, including isolates CMW42149, CMW42150 and CMW42157, formed a well-supported monophyletic clade (MLB and MPB $=100 \%, \mathrm{BPP}=1$ ). The third group of isolates, including CMW45100 and CMW45101, formed a cluster with G. lobatum, but represented a distinct lineage with high bootstrap values (MLB and MPB $=100 \%, \mathrm{BPP}=1$ ).

The combined dataset of the ITS, $\beta$-tubulin and TEF1- $\alpha$ sequences comprised 115 taxa and 1631 total characters. In this dataset the ITS, $\beta$-tubulin and TEF1- $\alpha$ respectively contributed 651, 401 and 579 characters. Of the total number of characters, 1152 were constant, 94 parsimony-uninformative and 385 were parsimony-informative. The heuristic search generated 100 parsimonious trees with $\mathrm{TL}=1005, \mathrm{CI}=0.541, \mathrm{RI}=0.878$, and $\mathrm{RC}=0.475$. Since the three analyses resulted in similar topologies, only the topology of the ML, incorporating BPP and MP bootstrap values, is presented (Fig. 6). The phylogeny for the combined dataset supported that of $\beta$-tubulin and TEF1- $\alpha$, placing the isolates obtained from A. cyclops at three different positions. A first group, consisting of the same 33 isolates as in the $\beta$-tubulin and TEF1- $\alpha$ phylogenies, formed a well-resolved monophyletic clade with strong statistical support (MLB $=88 \%$ and MPB $=98 \%$ ) in ML and MP analyses with isolates representing $G$. destructans. This clade was closely related to G. multipileum, but both formed distinct lineages. The second group, comprised of isolates CMW42149, CMW42150 and CMW42157, clustered in a clearly resolved monophyletic clade with strong statistical support $(\mathrm{MLB}$ and MPB $=100 \%, \mathrm{BPP}=1)$ in all three analyses. Finally, the third group, composed of isolates CMW45100 and CMW45101, formed a 


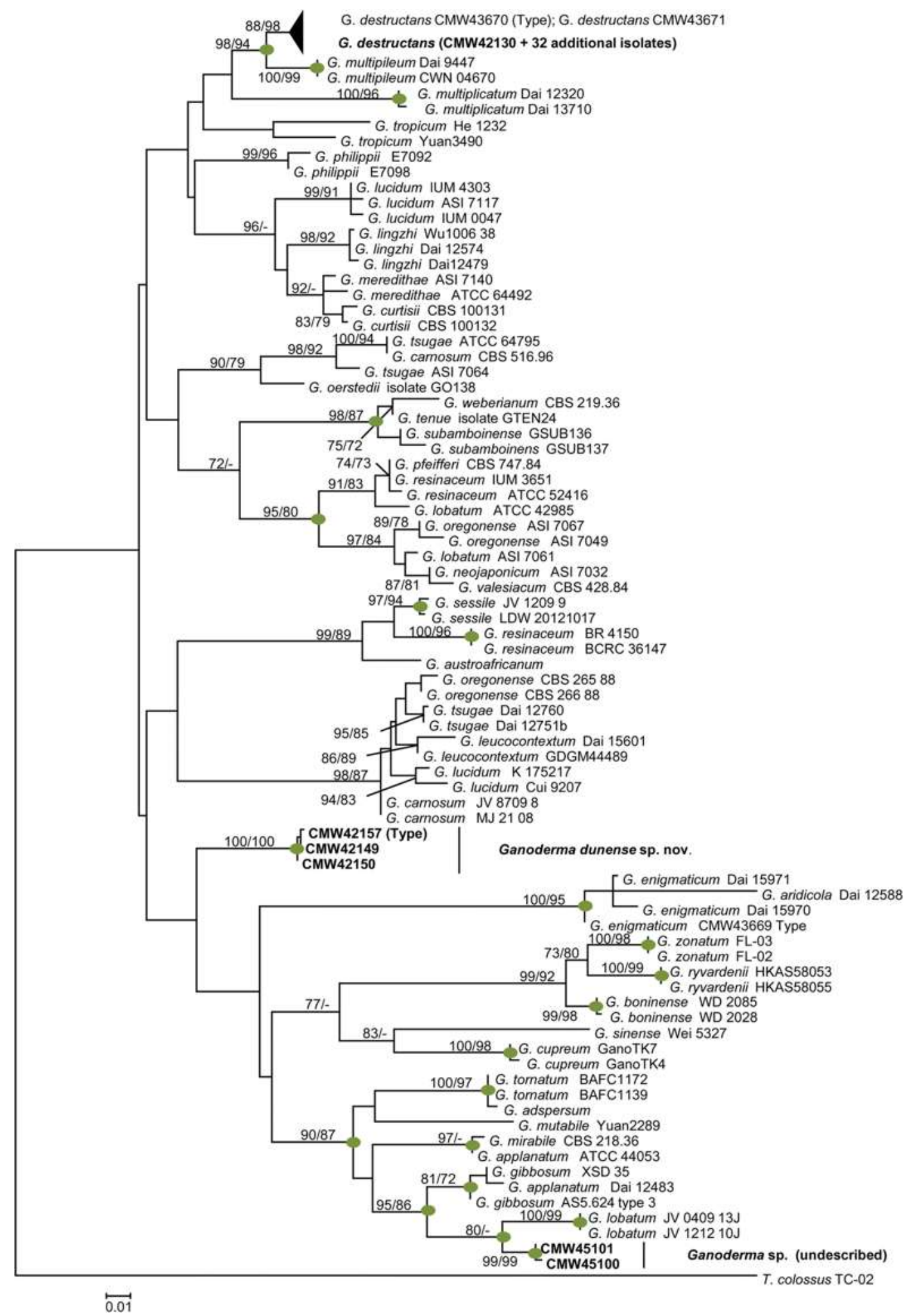

Fig. 6 Maximum likelihood tree based on combined dataset of ITS, $\beta$-Tubulin and TEF1- $\alpha$ gene sequences, depicting the phylogenetic position of the isolates obtained from Acacia cyclops (in bold) and related species within Ganoderma. Bootstrap values $\geq 70 \%$ from 1000 replicates of ML and MP analyses are displayed at the nodes. Posterior probability $\geq 0.95$ from Bayesian Inference analysis are indicated at nodes with green circles 
highly supported clade (MLB and MPB $=99 \%$, BPP $=1$ ), which was closely related to $G$. lobatum but with marginal support.

\section{Taxonomy}

Based on a phylogenetic species recognition concept, the 38 isolates of Ganoderma from A. cyclops in South Africa, represent three distinct taxa. One of these was G. destructans M.P.A. Coetzee, Marinc. \& M.J. Wingf. (Coetzee et al. 2015) and two others represented novel species. One of these novel taxa (CMW45100 and CMW45101) is not described because only a rudimentary and immature basidiome (Fig. 7) could be found for it. The other new species, represented by isolates CMW42149, CMW42150 and CMW42157 is described as follows:

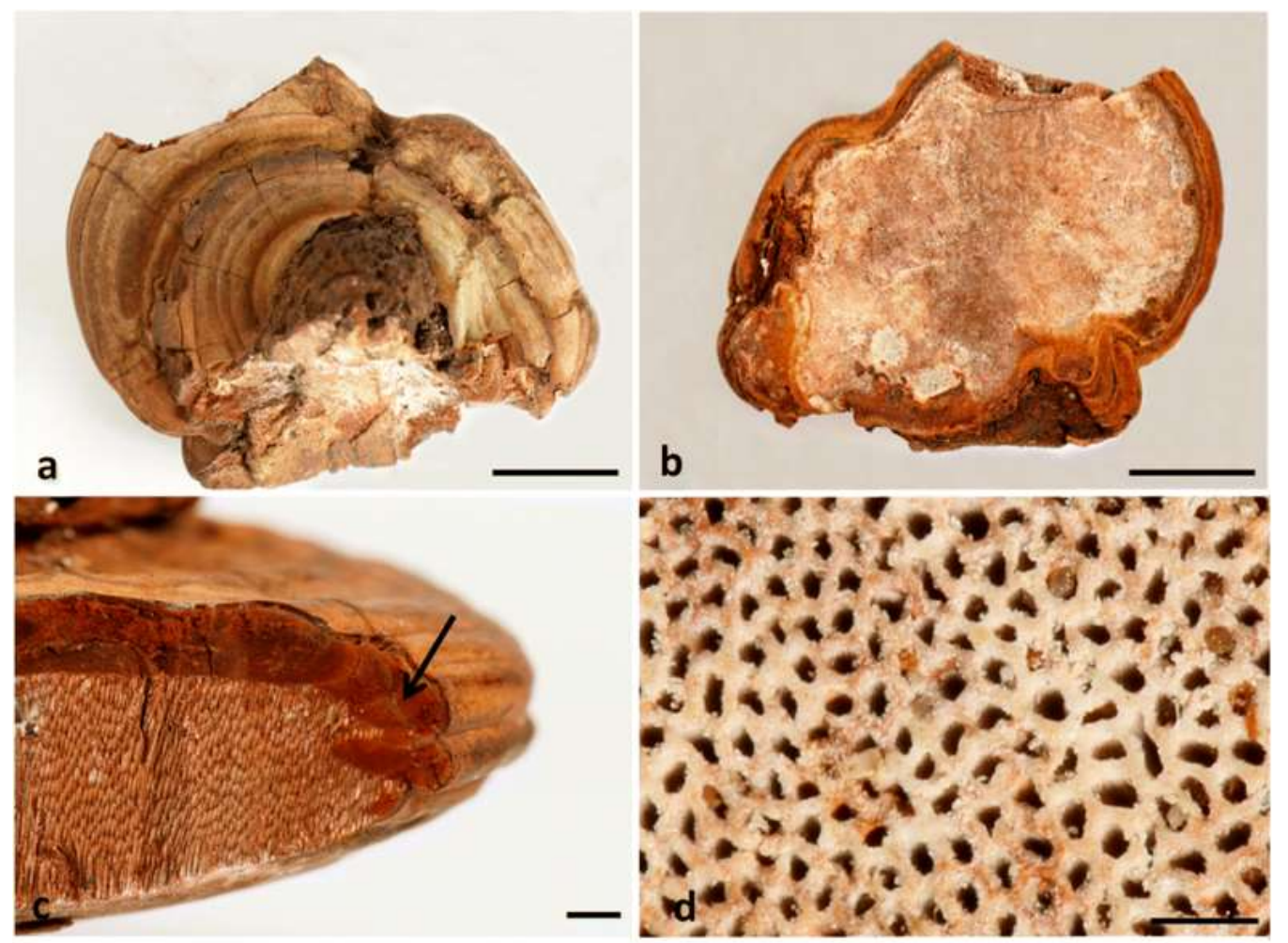

Fig. 7 Ganoderma sp. (a-b) pilear and hymenial surfaces of an immature basidiome; (c) homogenous chocolate brown context with discrete resin-like incrustations/deposits (arrowed); (d) pore surface. Bars: $\mathrm{a}-\mathrm{b}=2 \mathrm{~cm} ; \mathrm{c}=2$ $\mathrm{mm} ; \mathrm{d}=1 \mathrm{~mm}$ 

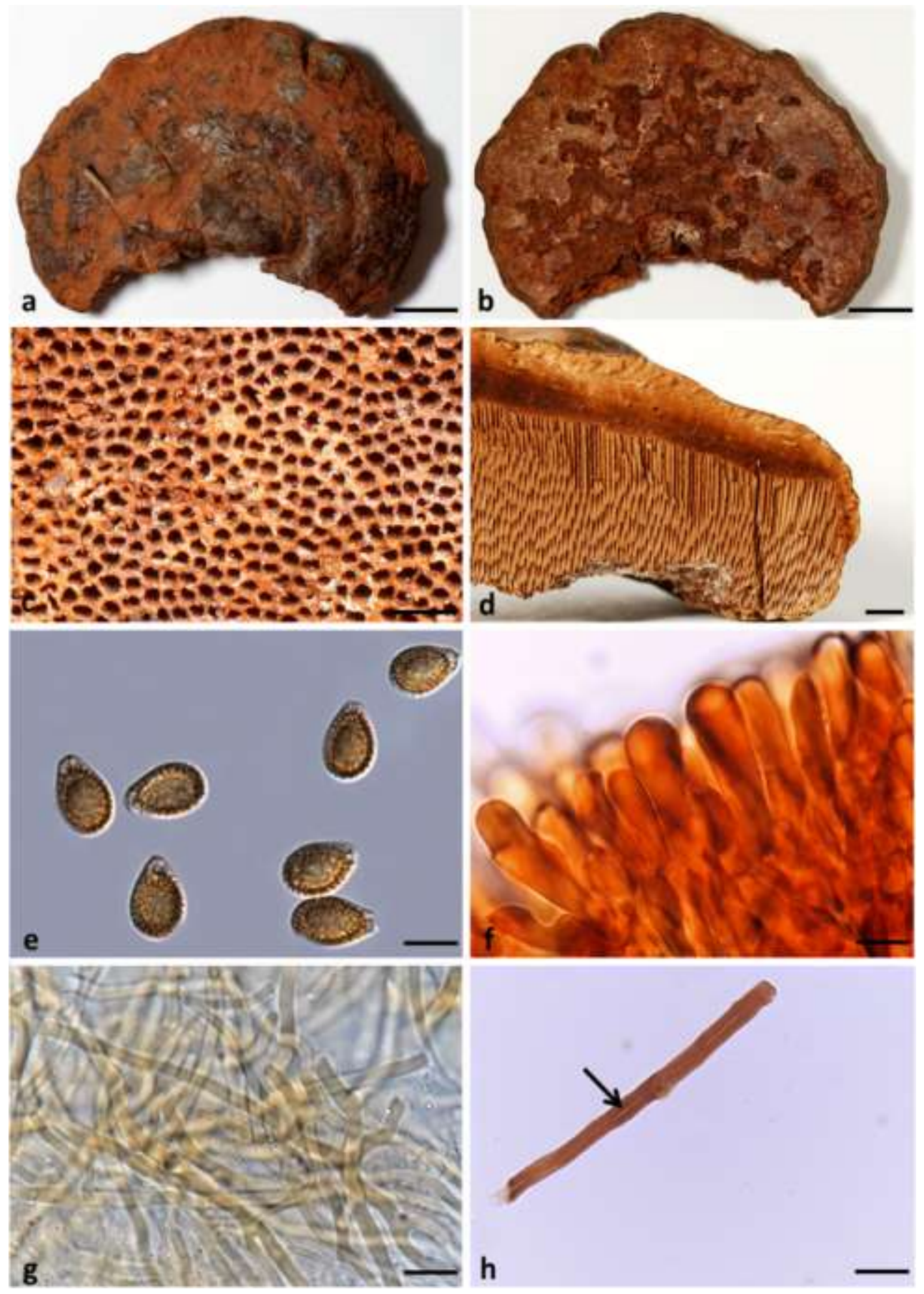

Fig. 8 Ganoderma dunense sp. nov. (Type, PREM 61936). (a-b) mature reniform-like basidiome showing a pileus surface partially covered with a dull brown deposit of basidiospores and a poroid dark brown hymenial surface; (c) pores; (d) duplex context with a light brown upper layer and a chocolate brown lower layer towards the tubes; (e) basidiospores; (f) palisade of clavi-form cutis cells; (g) skeletal hyphae; (h) skeletal hypha showing a distinct lumen (arrowed). Bars: $\mathrm{a}-\mathrm{b}=5 \mathrm{~cm} ; \mathrm{c}=1 \mathrm{~mm} ; \mathrm{d}=1 \mathrm{~cm} ; \mathrm{e}-\mathrm{h}=10 \mu \mathrm{m}$ 
Ganoderma dunense Tchotet, Rajchenb., \& Jol. Roux sp. nov.

MB823686

Fig. 8

Etymology: Name refers to the coastal sand dunes where this species was collected on dying $A$. cyclops trees.

Diagnosis: Ganoderma dunense is morphologically similar to species in the Ganoderma lucidum complex. It is characterised by a light and spongy, perennial, applanate, dimidiate or reniform, mucronate basidiome, a laccate shiny pilear surface and a thick, soft-spongy duplex context. Hymenial surface poroid, white when fresh. Hyphal system trimitic and basidiospores ovoid, 10.9-12.3 $\times 7.3-8.5 \mu \mathrm{m}$, double walled with hyaline exosporium and yellowish brown coarse echinulae endosporium, IKI-.

Type: South Africa, Western Cape Province, George, Heroldsbaai (S34 03.242' E22 $\left.22.711^{\prime}\right)$, at the base of dying Acacia cyclops A. Cunn. ex G. Don (Fabaceae), 13 April 2014, J.M. Tchotet Tchoumi and J. Roux, JMT137 (holotype-PREM61936, culture ex-type CMW42157 = CBS142831). GenBank accession number: ITS $=$ MG020255, $\beta$-tubulin $=$ MG020150, EF1- $\alpha=$ MG020227.

Description: Basidiomes light, with spongy consistency, perennial, applanate, dimidiate or reniform, up to $14-20 \mathrm{~cm}$ wide, $11-15 \mathrm{~cm}$ radius, and 2-2.5 $\mathrm{cm}$ thick at base, mucronate; mucro lateral, more or less ellipsoid, $2.3-5 \mathrm{~cm}$ long, $1.8-4 \mathrm{~cm}$ wide. Margins more or less circular, slightly lobate and round. Pileus surface laccate shiny, dark brown to dark brown chestnut, mostly covered by a dull brown deposit of basidiospores, glabrous, sulcate with wide furrows 
that become narrow towards the margins, and with irregular protuberances and a thin crust. Hymenial surface poroid, white when fresh turning brown to dark brown upon bruising; pores round to somewhat angular and elongated, 3-4 per mm; dissepiments thin. Context soft-spongy, 4-8 mm thick, duplex, with a light brown upper layer and a chocolate brown lower layer towards the tubes, absence of black resin-like deposits. Tubes light greyish brown, not stratified, up to 1.5 cm long. Hyphal system trimitic; generative hyphae not easily found, colourless, thin-walled, bearing clamp septa; skeletal hyphae poorly branched, brown to brown chestnut, thick-walled, 3.1-8 $\mu \mathrm{m}$ thick, lumen 1.4-2.2 $\mu \mathrm{m}$ wide; skeleto-binding hyphae present, branched at the apex with long flagelliform branches, basal stem unbranched. Cutis a hymeniodermis composed of a palisade of vertical and closely packed clavate cells; cells yellowish brown, thick-walled, some inflated at the apex and with rare growths of protuberances on the lateral parts, amyloid, 22.5$34.4 \times 5.4-10.6 \mu \mathrm{m}$. Cystidia and basidia not seen. Basidiospores ovoid with indistinct truncate apex, 10.9-12.3 × 7.3-8.5 $\mu \mathrm{m}(11.6 \pm 0.7 \times 7.9 \pm 0.6 \mu \mathrm{m})$, IKI-, double-walled, exosporium hyaline with inter-wall pillars, endosporium yellowish brown with coarse echinulae.

Additional specimen: South Africa, Western Cape Province, George, Heroldsbaai (S34 03.249’ E22 ${ }^{\circ} 22.720^{\prime}$ ), at the base of dying A. cyclops. 13 April 2014, J.M. Tchotet Tchoumi and J. Roux, JMT124 (paratype-PREM 61937, culture ex-type CMW42149 = CBS142945). GenBank accession number: ITS = MG020248, $\beta$-tubulin $=$ MG020153, EF1- $\alpha=$ MG020226.

Remarks: Ganoderma dunense and G. destructans cannot be distinguished from each other base on ITS phylogeny (Fig. 3). They segregate only in phylogenies for the $\beta$-tubulin and TEF1- $\alpha$ gene regions as well as in the combined genes (Figs 4, 5, 6). This phylogenetic divergence based on these three analyses is also reflected in some morphological characters. Morphologically, $G$. destructans differs from $G$. dunense in having a stipitate basidiome, a laccate shiny reddish 
brown pilear surface with well-developed protuberances, a not completely homogenous context, slightly smaller pores (3-5 per $\mathrm{mm})$ and larger basidiospores $(11-14 \times 7-9 \mu \mathrm{m}$, Coetzee et al. 2015; Table 2).

Ganoderma dunense is macroscopically similar to G. enigmaticum M.P.A. Coetzee, Marinc. \& M.J. Wingf., G. aridicola J.H. Xing \& B.K. Cui and G. austroafricanum M.P.A. Coetzee, M.J. Wingf., Marinc. \& Blanchette, with which it is genetically related (Fig. 6). They share the same origin (South Africa), a white poroid hymenophore surface when fresh, irregular pores and absence of black melanoid bands in the context (Crous et al. 2014; Coetzee et al. 2015; Xing et al. 2016; Table 2). However, G. enigmaticum and G. aridicola differ from G. dunense in their ecology. Ganoderma enigmaticum occurred as a parasite at the base of the trunk of Ceratonia siliqua L. in Pretoria, Gauteng Province (Coetzee et al. 2015), while G. aridicola was recovered on charred wood of Ficus in Durban, KwaZulu-Natal Province (Xing et al. 2016). In addition, G. enigmaticum differs morphologically from $G$. dunense by having a stipitate basidiome, homogenous context and narrower ellipsoid basidiospores $(8-11 \times 3.5-6 \mu \mathrm{m}$, Coetzee et al. 2015; Table 2). Similarly, G. aridicola differs from G. dunense by having a sessile basidiome, a fuscous homogenous context, distinctly stratified tube layers, smaller pores (6-8 per $\mathrm{mm}$ ) and broadly ellipsoid basidiospores (9.7-11.2 × 7-7.8 $\mu \mathrm{m}$, Xing et al. 2016; Table 2). G. austroafricanum has an annual sessile basidiome, a dimitic hyphal system and smaller (8-11 $\times 5.5-7 \mu \mathrm{m}$ ) subglobose basidiospores (Crous et al. 2014; Table 2).

When compared morphologically with other laccate Ganoderma species from South Africa and tropical Africa based on published descriptoins (Steyaert 1961, 1962, 1967, 1972, 1980; Table 2), G. dunense shares few characteristics with most of these species. Exceptions are G. namutambalaense Steyaert (1962), collected in Uganda and G. megalosporum Steyaert (1962) 
Table 2. Morphological comparison of G. dunense sp. nov. with other laccate Ganoderma taxa found in South Africa and tropical Africa

\begin{tabular}{|c|c|c|c|c|c|c|}
\hline Taxon & Shape & Pores/mm & Spores $(\mu \mathrm{m})$ & Cutis & Other & Reference \\
\hline Ganoderma africanum & NI & NI & NI & NI & type not found & $\begin{array}{l}\text { Moncalvo and } \\
\text { Ryvarden } 1997\end{array}$ \\
\hline G. aridicola & $\begin{array}{l}\text { sessile dimidiate, } \\
\text { pilear surface fuscous } \\
\text { black when fresh, } \\
\text { reddish brown to black } \\
\text { upon drying }\end{array}$ & $6-8$ & $\begin{array}{l}9.7-11.2 \times 7-7.8 \\
\text { broadly ellipsoid }\end{array}$ & $\begin{array}{l}\text { amyloid elements } 30-55 \times 5- \\
8 \mu \mathrm{m}\end{array}$ & $\begin{array}{l}\text { skeletal hyphae up } \\
\text { to } 2.5-5 \mu \mathrm{m} \text { wide }\end{array}$ & Xing et al. 2016 \\
\hline G. austroafricanum & sessile, dimidiate & $3-4$ & $\begin{array}{l}8-11 \times 5.5-7 \\
\text { broadly ellipsoid }\end{array}$ & NI & NI & Crous et al. 2014 \\
\hline \multirow[t]{2}{*}{ G. capensis } & sessile & $5-6$ & $9.75-10.5 \times 5.75-6.2$ & $\begin{array}{l}\text { elements } 50 \times 5-10 \mu \mathrm{m} \text { up to } \\
9-12 \mu \mathrm{m} \text { when capitate }\end{array}$ & $\begin{array}{l}\text { dimitic hyphal } \\
\text { system }\end{array}$ & Reid 1975 \\
\hline & - & 6 & $\begin{array}{l}10-12 \times 6-7 \\
\text { ovoid to ellipsoid }\end{array}$ & $\begin{array}{l}\text { amyloid elements } 35-45(-55) \\
\times 7-9 \mu \mathrm{m}\end{array}$ & $\begin{array}{l}\text { trimitic with } \\
\text { skeleteo-binding } \\
\text { hyphae, skeletal } \\
\text { hyphae } 5.5-10 \mu \mathrm{m} \\
\text { diam. }\end{array}$ & This publication \\
\hline \multirow[t]{2}{*}{ G. destructans } & $\begin{array}{l}\text { stipitate globular } \\
\text { pileus }\end{array}$ & $3-5$ & $11-14 \times 7-9$ & $\begin{array}{l}\text { amyloid elements } 13-35 \times \\
4.5-7.5\end{array}$ & $\begin{array}{l}\text { homogeneous } \\
\text { context }\end{array}$ & $\begin{array}{l}\text { Coetzee et al. } \\
2015\end{array}$ \\
\hline & $\begin{array}{l}\text { laccate shiny reddish } \\
\text { brown, stipe lateral to } \\
\text { eccentric and circular } \\
\text { to ellipsoid, pileus } \\
\text { dimidiate to circular, } \\
\text { with small to wide } \\
\text { protuberances }\end{array}$ & & - & - & $\begin{array}{l}\text { not completely } \\
\text { homogeneous } \\
\text { context }\end{array}$ & This publication \\
\hline
\end{tabular}


Table 2. (continued)

\begin{tabular}{|c|c|c|c|c|c|c|}
\hline Taxon & Shape & Pores/mm & Spores $(\mu \mathrm{m})$ & Cutis & Other & Reference \\
\hline G. dunense sp. nov. & $\begin{array}{l}\text { sessile but with a } \\
\text { lateral mucro, pileus } \\
\text { dimidiate or reniform }\end{array}$ & $3-4$ & $10.9-12.3 \times 7.3-8.5$ & $\begin{array}{l}\text { amyloid elements clavate, } \\
22.5-34.4 \times 5.4-10.6 \mu \mathrm{m}\end{array}$ & $\begin{array}{l}\text { duplex context } \\
\text { present }\end{array}$ & This publication \\
\hline G. enigmaticum & $\begin{array}{l}\text { stipitate globular } \\
\text { pileus }\end{array}$ & $3-5$ & $8-11 \times 3.5-6$ & $\begin{array}{l}\text { amyloid elements } 20-46 \times \\
5.5-9 \mu \mathrm{m}\end{array}$ & - & $\begin{array}{l}\text { Coetzee et al. } \\
2015\end{array}$ \\
\hline G. hildebrandii & $\begin{array}{l}\text { small basidiome } \\
\text { centrally stipitate }\end{array}$ & $7-8$ & $7-8(8.5) \times 4.5-5.5(-6)$ & $\begin{array}{l}\text { IKI- } \\
\text { elements similar but wider up } \\
\text { to } 15 \mu \mathrm{m}\end{array}$ & $\begin{array}{l}\text { dextrinoid skeletal } \\
\text { hyphae }\end{array}$ & $\begin{array}{l}\text { Moncalvo and } \\
\text { Ryvarden 1995, } \\
1997\end{array}$ \\
\hline G. reticulatosporum & $\begin{array}{l}\text { centrally stipitate } \\
\text { pileus, umbrella } \\
\text { shaped }\end{array}$ & $3-4$ & $25-26 \times 15.5-16$ & NI & $\begin{array}{l}\text { perhaps Humphreya } \\
\text { sp. }\end{array}$ & $\begin{array}{l}\text { Reid } 1973 \\
\text { Moncalvo and } \\
\text { Ryvarden } 1997\end{array}$ \\
\hline G. namutambalaense & $\begin{array}{l}\text { substipitate } \\
\text { flabellate }\end{array}$ & $5-6$ & $11.5-14 \times 8-9.5$ & $\begin{array}{l}\text { elements sphaeropedunculate, } \\
50 \times 4-7(-10) \mu \mathrm{m} \text {, sustaining } \\
\text { hyphae } 2-3 \mu \mathrm{m}\end{array}$ & from Uganda & Steyaert 1962 \\
\hline G. megalosporum & sessile dimidiate & $3-4$ & $11.5-13 \times 8-9$ & $\begin{array}{l}\text { elements subcylindric } \\
30 \times 4-6 \mu \mathrm{m}\end{array}$ & from Kenya & Steyaert 1962 \\
\hline
\end{tabular}

*NI refers to no information in the literature 
Table 3. Morphological comparison of G. dunense with its close relatives in the global multi-locus phylogeny (Fig. 6)

\begin{tabular}{|c|c|c|c|c|c|c|}
\hline Taxon & Shape & Pores/mm & Spores $(\mu \mathrm{m})$ & Cutis & Other & Reference \\
\hline G. carnosum. & $\begin{array}{l}\text { laterally to rarely } \\
\text { eccentrically stipitate, } \\
\text { dimidiate, orbicular to } \\
\text { reniform }\end{array}$ & $3-4$ & $10-13 \times 7-8.5$ & $\begin{array}{l}\text { amyloid elements up to } 75 \\
\mu \mathrm{m} \text { from clamp to the apex }\end{array}$ & $\begin{array}{l}\text { crust becoming } \\
\text { duller and darker } \\
\text { with age, presence } \\
\text { of protuberances }\end{array}$ & $\begin{array}{l}\text { Patouillard 1889; } \\
\text { Ryvarden and } \\
\text { Melo } 2014\end{array}$ \\
\hline G. dunense sp. nov. & $\begin{array}{l}\text { sessile but with a } \\
\text { lateral mucro, pileus } \\
\text { dimidiate or reniform }\end{array}$ & $3-4$ & $10.9-12.3 \times 7.3-8.5$ & $\begin{array}{l}\text { amyloid elements clavate, } \\
22.5-34.4 \times 5.4-10.6 \mu \mathrm{m}\end{array}$ & $\begin{array}{l}\text { duplex context } \\
\text { present }\end{array}$ & This publication \\
\hline G. leucocontextum & $\begin{array}{l}\text { stipitate, reniform, } \\
\text { dimidiate to } \\
\text { flabelliform }\end{array}$ & $4-6$ & $9.5-12.5 \times 7-9$ & $\begin{array}{l}\text { amyloid elements } 30-60 \times 8- \\
10 \mu \mathrm{m}\end{array}$ & $\begin{array}{l}\text { thinner context of } \\
\text { white to slightly } \\
\text { cream colour }\end{array}$ & Li et al. 2015 \\
\hline G. lucidum & $\begin{array}{l}\text { fan-shaped to } \\
\text { dimidiate; centrally to } \\
\text { laterally stipitate, } \\
\text { applanate }\end{array}$ & $4-5$ & $7-11 \times 6-8$ & $\begin{array}{l}\text { amyloid hyphal end cells up } \\
\text { to } 7-11 \mu \mathrm{m} \text { diam }\end{array}$ & $\begin{array}{l}\text { orange red to bay } \\
\text { upper surface; } \\
\text { deeper colour } \\
\text { context }\end{array}$ & $\begin{array}{l}\text { Ryvarden and } \\
\text { Gilbertson 1993; } \\
\text { Ryvarden and } \\
\text { Melo } 2014\end{array}$ \\
\hline G. oregonense & $\begin{array}{l}\text { sessile to substipitate } \\
\text { basidiome }\end{array}$ & $2-3$ & $13-17 \times 8-10$ & - & grow on conifers & $\begin{array}{l}\text { Gilbertson and } \\
\text { Ryvarden, } 1986\end{array}$ \\
\hline G. resinaceum & $\begin{array}{l}\text { stipitate, dimidiate to } \\
\text { broadly attached }\end{array}$ & $3-4$ & $9-11.5 \times 4.5-7$ & $\begin{array}{l}\text { amyloid elements up to } 50 \mu \mathrm{m} \\
\text { from clamp to the apex }\end{array}$ & $\begin{array}{l}\text { excretes a resinous } \\
\text { layer on the pileus } \\
\text { edge }\end{array}$ & $\begin{array}{l}\text { Ryvarden 2000; } \\
\text { Ryvarden and } \\
\text { Melo } 2014\end{array}$ \\
\hline G. sessile & $\begin{array}{l}\text { dimidiate, sessile } \\
\text { pileus sometimes } \\
\text { imbricate, conchate to } \\
\text { flabelliform }\end{array}$ & $4-5$ & $12-16 \times 6-8$ & $\begin{array}{l}\text { cylindric, smooth elements, } \\
60-75 \times 7-10 \mu \mathrm{m}\end{array}$ & $\begin{array}{l}\text { context thin, soft } \\
\text { corky or woody, } \\
\text { radially fibrous, } \\
\text { concentrically } \\
\text { zonate, ochraceous }\end{array}$ & $\begin{array}{l}\text { Murrill 1902; } \\
\text { Gottlieb and } \\
\text { Wright } 1999\end{array}$ \\
\hline G. tsugae & $\begin{array}{l}\text { fan-shaped to } \\
\text { dimidiate; centrally to } \\
\text { laterally stipitate }\end{array}$ & $4-6$ & $13-15 \times 7.5-8.5$ & - & $\begin{array}{l}\text { whitish and soft- } \\
\text { corky context; grow } \\
\text { on conifers }\end{array}$ & $\begin{array}{l}\text { Murrill 1902; } \\
\text { Gilbertson and } \\
\text { Ryvarden } 1986 \\
\end{array}$ \\
\hline
\end{tabular}


collected in Kenya, which share minor similarities with $G$. dunense. They can, however, easily be distinguished from $G$. dunense in that $G$. namutambalaense has a substipitate basidiome, smaller pores and larger basidiospores, while G. megalosporum has larger basidiospores and much smaller sub-cylindric cuticular cells (Table 2).

Other Ganoderma spp. phylogenetically closely related to G. dunense (Fig. 6) are compared in Table 3. They differ from G. dunense either in their ecology, features of the pilear surface, pore size, basidiospore shape and size, and/or their distribution.

\section{DISCUSSION}

Three distinct Ganoderma species were found associated with dying Acacia cyclops trees in the Eastern and Western Cape Provinces of South Africa. Two of these species represent novel taxa but a name was provided only for one due to absence of mature basidiomes needed to describe the second species. The description of the new species brings to 11 the Ganoderma spp. recorded from South Africa (Van del Bijl 1921; Reid 1973; 1974; 1975; Moncalvo and Ryvarden 1997; Crous et al. 2014; Coetzee et al. 2015 and Xing et al. 2016). Of these, only five have been described based on DNA sequence data.

The majority of Ganoderma isolates obtained in this study $(33=\sim 87 \%)$ represented $G$. destructans. This fungus was recently described as the causal agent of a serious root disease of non-native Jacaranda (Jacaranda mimosifolia D. Don) trees in the city of Pretoria (Tshwane Metropolitan area, Gauteng Province) in South Africa (Coetzee et al. 2015). The common occurrence of G. destructans on A. cyclops in the Western Cape, together with its occurrence on J. mimosifolia more than $1000 \mathrm{~km}$ further north in the country suggests that it does not only have 
a wide host range, but also wide geographical distribution. Based on the assertion of Coetzee et al. (2015) that this fungus might be a native species, $A$. cyclops thus represents the second nonnative host that it has successfully colonized. Its wide geographic distribution also supports the contention that it is a native South African fungus.

The two novel species of Ganoderma obtained from A. cyclops in this study were represented by only five isolates. Two were of the Ganoderma that was not describe and three were of the newly described $G$. dunense. Based on the appearance of the pilear surface, $G$. dunense could be linked to the G. lucidum complex, while the undescribed Ganoderma sp. was related to species in the G. applanatum complex (Imazeki 1952; Richter et al. 2015).

As has been found in many other studies (i.e. Gottlieb et al. 2000 and Zhou et al. 2015) sequence data for the ITS gene regions were not sufficient to delineate between $G$. dunense and G. destructans. Based on the ITS phylogeny, G. dunense would be treated as the same as $G$. destructans. But phylogenies inferred from the $\beta$-tubulin and TEF1- $\alpha$ data sets, as well as that of the combined genes, showed that this taxon represented a novel species. Morphological characterization also revealed very distinct macro- and microscopic characters that could further distinguish between these two taxa.

In the global multi-locus phylogeny, $G$. dunense formed a well-resolved monophyletic clade. However, it shared a genetic affinity with G. enigmaticum, G. aridicola, G. carnosum, G. lucidum (s. lat.), G. leucocontextum, G. tsugae, G. oregonense, G. austroafricanum, G. resinaceum and $G$. sessile. These species all reside in the G. lucidum complex subgenus Ganoderma (Li et al. 2015; Zhou et al. 2015; Richter et al. 2015). The phylogenetic relatedness 
of $G$. dunense to these species confirms its initial assignment to this complex based on morphology.

The extent of infection by Ganoderma species in this study raises an intriguing question about the role of $P$. acaciicola in the death of $A$. cyclops and whether it is the only causal agent of the deaths of these trees as reported by Wood and Ginns (2006). This question is worth noting because most of the isolates recovered from recently infected trees in the current study were of $G$. dunense and only a single isolate was identified as $P$. acaciicola. Moreover, although Ganoderma was included in the pathogenicity trials conducted by Wood and Ginns (2006), results of the present study show that at least three species of Ganoderma are associated with the dying A. cyclops in these areas. It is not known which of the three Ganoderma species was used in the aforementioned trials. Additionally, most of the sampled trees exhibited symptoms typical of Ganoderma root rot similar to those observed in previous studies (Glen et al. 2009; Coetzee et al. 2011). It is, therefore, clear that further investigations should be undertaken to determine the role of P. acaciicola and Ganoderma species in the death of A. cyclops trees in the coastal areas of South Africa.

\section{ACKNOWLEDGEMENTS}

We thank the Department of Science and Technology (DST), the National Research Foundation (NRF) and the International Cooperation Program (MINCYT-Argentina - DST-South Africa, SA/10/02) for funding. 


\section{REFERENCES}

Avis AM (1989) A review of coastal dune stabilization in the Cape Province of South Africa. Landsc Urban Plan 18: 55-68.

Bishop KS, Kao CHJ, Xu Y, Glucina MP, Paterson RRM, Ferguson LR (2015) From 2000 years of Ganoderma lucidum to recent developments in nutraceuticals. Phytochemistry 114: 56-65.

Coetzee MPA, Marincowitz S, Muthelo VG, Wingfield MJ (2015) Ganoderma species, including new taxa associated with root rot of the iconic Jacaranda mimosifolia in Pretoria, South Africa. IMA Fungus 6: 249-256.

Coetzee MPA, Wingfield BD, Golani GD, Tjahjono B, Gafur A, Wingfield MJ (2011) A single dominant Ganoderma species is responsible for root rot of Acacia mangium and Eucalyptus in Sumatra. South For 73: 175-180.

Crous PW, Wingfield MJ, Schumacher RK, Summerell BA, Giraldo A et al. (2014) Fungal Planet description sheets: 281-319. Persoonia 33: 212-289.

Darriba D, Taboada GL, Doallo R, Posada D (2012) "jModelTest 2: more models, new heuristics and parallel computing". Nat Methods 9: 772.

Douanla-Meli C, Langer E (2009) Ganoderma carocalcareus sp. nov., with crumbly-friable context parasite to saprobe on Anthocleista nobilis and its phylogenetic relationship in G. resinaceum group. Mycol Prog 8: 145-155.

Flood J, Bridge PD, Holderness M (Eds) (2000) Ganoderma diseases of perennial crops. (CABI Publishing: Wallingford, UK) 275 pp. 
Gilbertson RL, Ryvarden L (1986) North American polypores, vol 1. Fungiflora, Oslo.

Gill AM (1985) Acacia cyclops G. Don (Leguminosae: Mimosaceae) in Australia: distribution and dispersal. J R Soc West Aust 67: 59-65.

Glen M, Bougher NL, Francis AA, Nigg SQ, Lee SS, Irianto R, Barry KM, Beadle CL, Mohammed CL (2009) Ganoderma and Amauroderma species associated with root-rot disease of Acacia mangium plantation trees in Indonesia and Malaysia. Australas Plant Pathol 38: 345-356.

Gottlieb AM, Ferrer E, Wright JE (2000) rDNA analyses as an aid to the taxonomy of species of Ganoderma. Mycol Res 104: 1033-1045.

Gottlieb AM, Wright JE (1999) Taxonomy of Ganoderma from southern South America: subgenus Ganoderma. Mycol Res 103: 661-673.

Henderson L (1998) Invasive alien woody plants of the Southern and Southwestern Cape region, South Africa. Bothalia 28: 91-112.

Henderson L (2007) Invasive, naturalized and casual alien plants in southern Africa: a summary based on the Southern African Plant Invaders Atlas (SAPIA). Bothalia 37: 215-248.

Hong SG, Jung HS (2004) Phylogenetic analysis of Ganoderma based on nearly complete mitochondrial small-subunit ribosomal DNA sequences. Mycologia 96: 742-755

Imazeki R (1952) A contribution to the fungus flora of Dutch New Guinea. Bull Gov Forest Exp Sta, Meguro. Tokyo 57:87-128

Katoh K, Standley DM (2013) MAFFT Multiple sequence alignment software version 7: improvements in performance and usability. Mol Biol Evol 30: 772-780. 
Kauserud H, Schumacher T (2001) Outcrossing or inbreeding: DNA markers provide evidence for type of reproductive mode in Phellinus nigrolimitatus (Basidiomycota). Mycol Res 53: 220230.

Kinge TR, Mih AM (2011) Ganoderma ryvardense sp. nov. associated with basal stem rot (BSR) disease of oil palm in Cameroon. Mycosphere 2: 179-188.

Kinge TR, Mih AM, Coetzee MPA (2012) Phylogenetic relationships among species of Ganoderma (Ganodermataceae, Basidiomycota) from Cameroon. Aust J Bot 60: 526-538.

Kirk PM, Cannon PF, Minter DW, Stalpers JA (2008) Dictionary of the fungi, 10th edn. CAB International, Wallingford.

Kotzé LJD, Wood AR, Lennox CL (2015) Risk assessment of the Acacia cyclops dieback pathogen, Pseudolagarobasidium acaciicola, as a mycoherbicide in South African strandveld and limestone fynbos. Biol Control 82: 52-60.

Li TH, Hu HP, Deng WQ, Wu SH, Wang DM, Tsering T (2015) Ganoderma leucocontextum, a new member of the G. lucidum complex from Southwestern China. Mycoscience 56: 81-85.

Miller MA, Pfeiffer W, Schwartz T (2010) "Creating the CIPRES Science Gateway for inference of large phylogenetic trees" in Proceedings of the Gateway Computing Environments Workshop (GCE), 14 Nov. 2010, New Orleans, LA pp 1 - 8.

Möller EM, Bahnweg G, Sandermann H, Geiger HH (1992) A simple and efficient protocol for isolation of high molecular weight DNA from filamentous fungi, fruit bodies, and infected plant tissues. Nucleic Acids Res 20: 6115-6116. 
Moncalvo JM, Buchanan PK (2008) Molecular evidence for long distance dispersal across the Southern Hemisphere in the Ganoderma applanatum-australe species complex (Basidiomycota). Mycol Res 112: 425-436.

Moncalvo JM, Ryvarden L (1997) A nomenclatural study of the Ganodermataceae Donk. Synopsis Fungorum 11. Fungiflora : Oslo, Norway.

Murrill, WA (1902) The Polyporaceae of North America: I. The genus Ganoderma. Bull Torrey Bot Club 29:599-608.

Park Y, Kwon O, Son E, Yoon D, Han W, Yoo Y, Lee C (2012) Taxonomy of Ganoderma lucidum from Korea Based on rDNA and Partial $\beta$-tubulin Gene Sequence Analysis. Mycobiology 40: $71-75$.

Paterson RRM (2007) Ganoderma disease of oil palm-A white rot perspective necessary for integrated control. Crop Prot 26: 1369-1376.

Patouillard N (1889) Le genre Ganoderma. Bulletin de la Société Mycologique de France 5 : p 64.

Ramasamy S (1972) Cross-infectivity and decay ability of Ganoderma species parasitic to rubber, oil palm and tea. In: Ganoderma diseases of perennial crops. Flood J, Bridge PD and Holderness M, 2000. CABI, Wallingford, UK.

Reid DA (1973) A reappraisal of type and authentic specimens of Basidiomycetes in the Van der Byl Herbarium, Stellenbosch. S Afr J Bot 39: 141-178.

Reid DA (1974) A reappraisal of type and authentic material of the larger Basidiomycetes in the Pretoria Herbarium. Bothalia 11: 221-230. 
Reid DA (1975) Type studies of the larger Basidiomycetes described from southern Africa. Contributions from the Bolus Herbarium 7: 1-255.

Richter C, Wittstein K, Kirk P, Stadler M (2015) An assessment of the taxonomy and chemotaxonomy of Ganoderma. Fungal Divers 71: 1-15.

Ronquist F, Teslenko M, van der Mark P et al. (2012) MrBayes 3.2: efficient Bayesian phylogenetic inference and model choice across a large model space. Syst Biol 61: 539-542.

Ryvarden L (1985) Type studies in the Polyporaceae 17. Species described by W. A. Murrill. Mycotaxon 23: 169-198.

Ryvarden L (2000) Studies in neotropical polypores 2: a preliminary key to neotropical species of Ganoderma with a laccate pileus. Mycologia 92:180-191

Ryvarden L, Gilbertson RL (1993) European Polypores. Part 1. Abortiporus Lindtneria. Synopsis Fungorum 6: 1-387.

Ryvarden L, Melo I (2014) Poroid fungi of Europe. Synopsis Fungorum 31: 1-455.

Shackleton CM, McConnachie M, Chauke MI, Mentz J, Sutherland F, Gambiza J and Jones R, (2006) Urban fuelwood demand and markets in a small town in South Africa: Livelihood vulnerability and alien plant control. Int J Sustain Dev World Ecol 13: 481-491.

Silvestro D, Michalak I (2012) raxmlGUI: a graphical front-end for RAxML. Org Divers Evol 12: $335-337$.

Stamatakis A (2006) RAxML-VI-HPC: Maximum likelihood-based phylogenetic analyses with thousands of taxa and mixed models. Bioinformatics 22: 2688-2690. 
Steyaert RL (1961) Genus Ganoderma (Polyporaceae) taxa nova - I. In Bulletin du Jardin Botanique de l'État à Bruxelles 31: 69-83.

Steyaert RL (1962) Genus Ganoderma (Polyporaceae) taxa nova-2. In Bull du Jard Bot Natl Belgique 32: 89-104.

Steyaert RL (1967) Les Ganoderma palmicoles. Bull du Jard Bot Natl Belgique 37: 465-492.

Steyaert RL (1972) Species of Ganoderma and related genera mainly of the Bogor and Leiden Herbaria. Persoonia 7: 55-118.

Steyaert RL (1980) Study of some Ganoderma species. Bull du Jard Bot Natl Belgique 50: 135-186.

Swofford DL (2002) PAUP*: phylogenetic analysis using parsimony (*and other methods). Version 4. Sunderland, MA: Sinauer Associates.

Tamura K, Peterson D, Peterson N, Stecher G, Nei M, Kumar S (2011) MEGA 5: molecular evolutionary genetics analysis using maximum likelihood, evolutionary distance, and maximum parsimony methods. Mol Biol Evol 28: 2731-2739.

Taylor H (1969) Pest plants and nature conservation in the winter rainfall region. J Bot Soc South Africa 55: 32-35.

Van der Bijl PA (1921) A contribution to our knowledge of the Polyporeae of South Africa. S Afr J Sci 18: 246-293.

White TJ, Bruns T, Lee S, Taylor J (1990) Amplification and direct sequencing of fungal ribosomal RNA genes for phylogenetics In: Innis MA, Gelfand DH, Sninsky JJ, White TJ (Eds), PCR Protocols: a guide to methods and applications. Academic Press, New York. pp. 315-322. 
Wood AR, Ginns J (2006) A new dieback disease of Acacia cyclops in South Africa caused by Pseudolagarobasidium acaciicola sp. nov. Can J Bot 84: 750-758.

Worrall JJ (1991) Media for selective isolation of hymenomycetes. Mycologia 83: 296-02.

Xing JH, Song J, Decock C, Cui BK (2016) Morphological characters and phylogenetic analysis reveal a new species within the Ganoderma lucidum complex from South Africa. Phytotaxa 266: $115-124$.

Zhou LW, Cao Y, Wu SH, Vlasák J, Li DW, Li MJ, Dai YC (2015) Global diversity of the Ganoderma lucidum complex (Ganodermataceae, Polyporales) inferred from morphology and multilocus phylogeny. Phytochemistry 114: 7-15. 